\title{
Microbiota Associated with Sclerotia of Soilborne Fungal Pathogens - A Novel Source of Biocontrol Agents Producing Bioactive Volatiles
}

\author{
Pascal Mülner, ${ }^{1,2}$ Alessandro Bergna, ${ }^{1,3}$ Philipp Wagner, ${ }^{1}$ Dženana Sarajlić, ${ }^{1}$ Barbara Gstöttenmayr, ${ }^{1,2}$ \\ Kristin Dietel, ${ }^{2}$ Rita Grosch, ${ }^{4}$ Tomislav Cernava, ${ }^{1, \dagger}$ and Gabriele Berg ${ }^{1}$ \\ ${ }^{1}$ Institute of Environmental Biotechnology, Graz University of Technology, Petersgasse 12, 8010 Graz, Austria \\ ${ }^{2}$ ABiTEP GmbH, Glienicker Weg 185, 12489 Berlin, Germany \\ ${ }^{3} \mathrm{ACIB} \mathrm{GmbH}$, Petersgasse 14, $8010 \mathrm{Graz}$, Austria \\ ${ }^{4}$ Plant-Microbe Systems, Leibniz Institute of Vegetable and Ornamental Crops, Großbeeren, Germany \\ Accepted for publication 07 April 2019.
}

\section{ABSTRACT}

Soilborne plant pathogens are an increasing problem in modern agriculture, and their ability to survive long periods in soil as persistent sclerotia makes control and treatment particularly challenging. To develop new control strategies, we explored bacteria associated with sclerotia of Sclerotinia sclerotiorum and Rhizoctonia solani, two soilborne fungi causing high yield losses. We combined different methodological approaches to get insights into the indigenous microbiota of sclerotia, to compare it to bacterial communities of the surrounding environment, and to identify novel biocontrol agents and antifungal volatiles. Analysis of $16 \mathrm{~S}$ rRNA gene fragment amplicons revealed significant compositional differences in the bacterial microbiomes of Rhizoctonia sclerotia, the unaffected tuber surface and surrounding soil. Moreover, distinctive bacterial lineages were associated with specific sample types. Flavobacteriaceae and Caulobacteraceae were primarily found in unaffected areas, while Phyllobacteriaceae and Bradyrhizobiaceae were associated with sclerotia of $R$. solani. In parallel, we studied a strain collection isolated from sclerotia of the pathogens for emission of bioactive volatile compounds. Isolates of Bacillus, Pseudomonas, and Buttiauxella exhibited high antagonistic activity toward both soilborne pathogens and were shown to produce novel, not yet described volatiles. Differential imaging showed that volatiles emitted by the antagonists altered the melanized sclerotia surface of S. sclerotiorum. Interestingly, combinations of bacterial antagonists increased inhibition of mycelial growth up to $60 \%$ when compared with single isolates. Our study showed that fungal survival structures are associated with a specific microbiome, which is also a reservoir for new biocontrol agents.

Keywords: agriculture, biocontrol consortia, ecology, microbial volatile organic compounds, microbiome, Rhizoctonia solani, Sclerotinia sclerotiorum, Solanum tuberosum
Soilborne pathogens are often limiting factors for crop yield and quality in various agricultural ecosystems, and therefore, a major

\section{${ }^{\dagger}$ Corresponding author: T. Cernava; tomislav.cernava@tugraz.at}

Funding: This project is part of the BestPass International Training Network funded by the European Union's Horizon 2020 research and innovation programme under the H2020 Marie Skłodowska-Curie Actions grant agreement number 676480.

Second and third authors contributed equally to the study.

*The $\boldsymbol{e}$-Xtra logo stands for "electronic extra" and indicates that six supplementary figures and three supplementary tables are published online.

The author(s) declare no conflict of interest.

(C) 2019 The American Phytopathological Society issue worldwide (Allan et al. 2010; Raaijmakers et al. 2009; Weller et al. 2002). Fungi, oomycetes, and nematodes play important roles when underground plant parts are affected, and often act together in infection and disease (Raaijmakers et al. 2009). Soilborne fungi, which represent a major group of these pathogens, are characterized by a parasitic life cycle in their host plants, but they are also capable to endure in soil as saprophytes on plant residues or as survival structures from several weeks up to many years (Haas and Défago 2005; Lucas 2006). Examples for important soilborne fungi, which cause serious yield losses in a broad crop range, are Rhizoctonia solani Kühn (teleomorph Thanatephorus cucumeris [Frank] Donk) and Sclerotinia sclerotiorum (Lib.) de Bary (1884). Both produce persistent sclerotia as survival structures, which makes outbreak predictions difficult and aggravates their control (Davis et al. 1994; Koike et al. 2003). In addition to the broad host range of $R$. solani, including 
multiple economically important crops (Ogoshi 1987; Sneh et al. 1996), its saprophytic lifestyle is an aggravating challenge in crop farming (Grosch et al. 2005). In the last years, several broad-spectrum as well as specific fungicides were developed to control Rhizoctonia, but the negative effects of various chemicals on the ecological balance of soil microorganisms, rising resistances, and groundwater pollution make them nonsustainable solutions for future crop protection (Mnif et al. 2016; Scherwinski et al. 2008). Traditionally, specific crop rotations were implemented to manage soilborne pathogens and avoid their accumulation in soil. In contrast, intensive management practices come along with negative consequences related to these pathogens, because they accumulate in the soil and simultaneously enhance disease pressure on crops over time (Weller et al. 2002). Currently, Rhizoctonia and Sclerotinia belong to the most important soilborne fungal pathogens; thus, novel approaches are needed to suppress their abundance and survival in order to avoid disease outbreaks and yield losses (Mendes et al. 2011).

Phytobiome studies have revealed that plant-associated microorganisms offer natural solutions for the suppression of soilborne pathogens, because one of their main functions is to protect plants against biotic and abiotic stresses (Berendsen et al. 2012; Berg et al. 2016; Vandenkoornhuyse et al. 2015). Biological control of plant pathogens by naturally occurring antagonists was identified as a sustainable and environmentally friendly plant protection approach a long time ago (Whipps 2001; Weller et al. 2002); however, due to the substantial progress in our understanding of the functioning of the plant microbiome, it recently became feasible to develop knowledge-based and predictable protection approaches (Mendes et al. 2011). Moreover, there is now the possibility to exploit the plant microbiota as a whole as well as other environmental microbiota for advanced plant protection strategies (Berg et al. 2013). While the rhizosphere was often the main target to identify successful biocontrol agents (Burr et al. 1978; Kloepper 1981; Weller et al. 2002), fungal structures were also identified as distinct habitat for antagonistic bacteria (Frey-Klett et al. 2011; Schmidt et al. 2016). Interestingly, fungal symbionts can also interact with the pathogens themselves as shown in a previous study, where Enterobacter was shown to enhance virulence of $R$. solani AG22IIIB (Obasa et al. 2017). However, there is still a lack of knowledge related to sclerotia-associated microbiota, especially when addressed with cultivation-independent tools (Zachow et al. 2011).

The objective of this study was to investigate bacterial communities associated with fungal survival structures, in order to (i) identify potential, bacterial biomarkers in $R$. solani-infected potatoes, (ii) isolate novel biocontrol agents, and (iii) provide evidence for improved efficacy of biocontrol consortia via complementation. In our experimental design, analyses of microbial volatile organic compounds (mVOCs) were included, because of their importance as communication molecules and powerful weapons for the suppression of pathogens (Kanchiswamy et al. 2015; Ryu et al. 2003; Wenke et al. 2012). Moreover, they can be involved in plant growth stimulation and restriction of fungal growth without physical contact, but are still understudied (Cernava et al. 2015; Ryu 2004; Schmidt et al. 2015). We have included them in our study to (i) reveal the impact of mVOCs on sclerotia viability, and (ii) describe the volatilomes of distinct antagonistic bacteria. Our poly-phasic approach included amplicon sequencing of $16 \mathrm{~S}$ rRNA gene fragments combined with bioinformatic analyses, confocal laser scanning microscopy (CLSM), as well as isolate-based analyses to assess antagonistic effects toward pathogens and characterize their mVOCs with gas chromatography-mass spectrometry (GC-MS) experiments. Two sclerotia-forming model organisms were employed in order to make use of their specific morphology and lifestyles. While
$R$. solani is an ideal model for three-way interactions (fungus, host plant, microbiome), the minor size of its sclerotia and attachment to the host aggravates in vitro experiments and observations related to morphological changes. Therefore, the significantly larger sclerotia of $S$. sclerotiorum were chosen to visualize the effects of $m V O C s$ on their viability.

\section{MATERIALS AND METHODS}

Isolation of potential biocontrol agents from fungal sclerotia. Bacteria were isolated from $R$. solani sclerotia-infected potato tubers and a bait system with sclerotia from $S$. sclerotiorum. For the first approach naturally infected tubers were obtained from a field in Sanitz (Germany, latitude 54.07 I longitude 12.35). Visual inspection of the tubers (Solanum tuberosum L. 'Gala') resulted in a classification into three sample types on each tuber: tuber surface without sclerotia, surface area with microsclerotia and surface area with macrosclerotia on tubers (10 samples per group). Adherent soil (five samples) was obtained for comparisons with the tuber material. The dissected samples were homogenized in $1.5 \mathrm{ml}$ of $0.85 \%$ $\mathrm{NaCl}$ and serial dilutions were plated on Reasoner's 2A-Agar (R2A-Agar; Carl Roth GmbH Co. KG) with and without cycloheximide at $20 \mu \mathrm{g} / \mathrm{ml}$. In total, 400 bacteria (100 per sample type: macrosclerotia $[\mathrm{MS}]$, microsclerotia $[\mathrm{mS}]$, tuber surface [Ts], surrounding soil [So]) were isolated by randomized selection of bacterial colony forming units (CFU). In an additional approach a bait system was employed for the isolation of antagonistic bacteria from sclerotia as already described by Zachow et al. (2011). For this purpose, sclerotia of S. sclerotiorum Goa11 (strain collection of the Institute of Environmental Biotechnology-Graz University of Technology) were cultivated on potato-dextrose agar (PDA) (Carl Roth, Germany) in Petri dishes and packed in sealed sachets made of sterilized nylon. Sachets containing 20 sclerotia were buried in a depth of 10 to $15 \mathrm{~cm}$ in four different soil types (sand [S], peat [T], compost $[\mathrm{K}]$, and beech forest $[\mathrm{B}]$ ) to attract bacteria from these soils. Three sclerotia bait systems per soil type remained underground for the enrichment of potential soilborne bacterial antagonists for 7 days (02/06/2016 to 09/06/2016) at the botanical garden of the University of Graz (Austria, latitude 47.08 I longitude 15.46). The recovery of sclerotia was followed by a homogenization in $0.85 \% \mathrm{NaCl}$ solution and plating on Reasoner's 2A-Agar (R2AAgar; Carl Roth). Cycloheximide $(20 \mu \mathrm{g} / \mathrm{ml})$ was added to a subset of R2A-Agar plates to prevent fungal growth. The isolated 160 bacterial isolates were designated according to the originated soil type (S, T, K, and B) and the usage of cycloheximide (C) during the isolation.

Extraction of total community DNA and barcoded primer 16S rDNA PCR. The DNA extraction from the same $R$. solani sclerotia samples that were used for the isolation of antagonistic bacteria was carried out by using the MP FastDNA Kit for soil (MP Biomedicals, U.S.A.). After following the manufacturer's protocol, the extracted total community DNA from $R$. solani-infected potato samples served as template for the 16S rDNA fragment amplification. The universal bacterial primers 515f/806r were used to target the hypervariable V4 region of 16S rRNA (Caporaso et al. 2011). Distinctive barcodes were utilized to label each sample. Purification of pooled DNA fragments was performed with the Promega (Madison, U.S.A.) Wizard SV GeL and PCR Clean-Up System Kit. Paired-end Illumina HiSeq sequencing of barcoded samples was conducted at GATC Biotech (Konstanz, Germany).

Data analysis of $16 \mathrm{~S}$ rDNA amplicons for microbial community analyses. The $16 \mathrm{~S}$ rRNA gene fragment library went through an initial quality check, where only forward reads were selected, which subsequently underwent demultiplexing and quality 
filtering with QIIME (Quantitative Insights into Microbial Ecology, version 1.9.0; Caporaso et al. 2010) default parameters. Dereplication of high quality reads and clustering with a similarity threshold of $97 \%$ was conducted with vsearch (QIIME plugin). After creating a set of representative sequences, chimeras were filtered via both denovo reference-based approaches while mapping high quality sequences (vsearch). The taxonomical assignment was obtained by employing QIIME environment rdp (default parameters) in combination with the SILVA 16S database. Unassigned operational taxonomic units (OTUs; $0.75 \%$ of all OTUs) and contaminants were filtered from the resulting OTU table. Alpha and beta diversity estimates, and rarefaction plots were generated by usage of the QIIME standard pipeline. An unrarefied table filtered for OTUs accounting for $\geq 0.25 \%$ in at least one of the four habitats was used to track the distribution of OTUs in the sampling set and allowed to discern between unique and ubiquitous OTUs (Supplementary Table S1). For the visualization in histograms, all taxa with a relative abundance $\leq 0.5 \%$ were neglected. The $16 \mathrm{~S}$ rRNA Illumina libraries were deposited at the European Nucleotide Archive (ENA) under the project number PRJEB28442.

In vitro screening of antagonistic traits of bacterial isolates. The isolates' antagonistic activity toward S. sclerotiorum Goa11 and $R$. solani San 16 (both from the strain collection of the Institute of Environmental Biotechnology-Graz University of Technology) was assessed with dual-culture in vitro assays at room temperature (Berg et al. 2002; Opelt et al. 2007). Fungi and bacterial isolates were cultured on the same plate of Waksman agar and visually inspected following the incubation phase (Zachow et al. 2011). Zones of inhibition and browning of the mycelium, due to the production of melanin, were indicators for antagonistic effects. Specimens were assorted into four different degrees of inhibition: no inhibition, no overgrowing of bacteria by fungus, zone of inhibition of $\leq 10 \mathrm{~mm}$, and zone of inhibition of $>10 \mathrm{~mm}$.

Effect of bacterial volatiles on mycelial growth of S. sclerotiorum and $\boldsymbol{R}$. solani. Preselected bacterial strains were tested in terms of their ability to inhibit mycelial growth of $S$. sclerotiorum and $R$. solani using a Petri dish VOCs assay (PDVA). Two petri dish bottoms (Carl Roth), one with nutrient agar (NA, Sifin, Germany) and one with PDA (Carl Roth), were placed over each other and sealed. Growth inhibition was assessed by comparison of mycelial growth to untreated fungi when the controls grew close to the edges of well plates.

Assessment of the volatilome of potential biocontrol strains using a GC-MS volatile assay. Headspace vials $(20 \mathrm{ml} ; 75.5 \times$ $22.5 \mathrm{~mm}$; Chromtech, Idstein, Germany) were filled with $8 \mathrm{ml}$ of NA (Carl Roth) for the cultivation of bacteria. The bacterial isolates were streaked on the agar in parallel lines to assure equal distribution in three vials per organism. After $24 \mathrm{~h}$ of incubation at $30^{\circ} \mathrm{C}$, the volatiles accumulating inside the vials were analyzed via headspace solid phase microextraction (HS-SPME) GC-MS. Compound separation and detection was performed on a system combining a GC 7890A with a quadrupol MS 5975C (Agilent Technologies, Waldbronn, Germany). SPME fibers consisting of divinylbenzene/carboxen/polydimethylsiloxane (DVB/CAR/PDMS) polydimethylsiloxane/divinylbenzene (PDMS/DVB) were used for sampling (Sigma-Aldrich, St. Louis, U.S.A.). HS samples were separated in a (5\%-phenyl) methylpolysiloxane column, $60 \mathrm{~m} \times$ $0.25 \mathrm{~mm}$ i.d., $0.25 \mu \mathrm{m}$ film thickness (DB-5MS; Agilent Technologies). Electron ionization with $70 \mathrm{eV}$ and detection (mass range 25 to 350 ) were performed subsequently. The fiber was desorbed at $200^{\circ} \mathrm{C}$ for $8 \mathrm{~min}$ to eliminate potential residues before initial measurements, and $270^{\circ} \mathrm{C}$ was adjusted for the inlet temperature. The temperature gradient of the column was maintained at $70^{\circ} \mathrm{C}$ for 1.5 min, raised to $200^{\circ} \mathrm{C}$ at a rate of $16^{\circ} \mathrm{C} / \mathrm{min}$, and finally kept at $200^{\circ} \mathrm{C}$ for $0.5 \mathrm{~min}$. The helium flow rate was adjusted to $1.2 \mathrm{ml} / \mathrm{min}$. For identification of mVOCs, the detected spectra were matched to the NIST MS Database 14 via MS Search 2.2. For each compound, the Kovats index (KI) was calculated and compared with database entries in the online database Chemspider (http://www.chemspider.com/) for further verification of the identified mVOCs.

Taxonomical assignment of bacterial antagonists. Fragments of bacterial $16 \mathrm{~S}$ rRNA genes were amplified using the primers $27 \mathrm{f}$ and 1492r (Frank et al. 2008) for taxonomic identifications of the potential biocontrol agents. The Wizard SV Gel and PCR Clean-Up System (Promega) was used for the purification of PCR products, which were subsequently sequenced by LGC Genomics (Berlin, Germany). The resulting sequences were compared with database entries with NCBI's nucleotide BLAST (https://blast.ncbi.nlm.nih.gov/Blast.cgi).

Cross-sections and micrographs of $\mathbf{m V O C}$-treated sclerotia. Sclerotia of $S$. sclerotiorum were exposed to mVOCs of prescreened bacteria to evaluate their effect on the survival structures. Therefore, $100 \mu \mathrm{l}$ of bacterial suspensions with an $\mathrm{OD}_{600}$ value between 0.4 and 0.7 was plated onto Petri dishes with NA. The Petri dishes were incubated upside down, whereas sclerotia were placed on the lid. The incubation amounted to a total of 27 days where bacterial plates were exchanged every 3 days. Untreated sclerotia and a treatment with Escherichia coli K12 served as controls. Subsequently, the untreated and treated sclerotia were incubated on PDA plates to evaluate potential effects of bacterial volatiles on their germination ability. Visualization of the effect of volatiles on sclerotia of $S$. sclerotiorum was performed on both macroscopic and microscopic level. Cross-sections of these survival structures were prepared and visualized by using a type M3B binocular from Virtual Archive of WILD Herrbugg (Switzerland) with 40× magnification. These thin layers were later stained with a LIVE/DEAD FungaLight Yeast Viability Kit (L34592, Molecular Probes, Life Technologies). The kit contains two different nucleic acid dyes: one, SYTO 9 green, is able to penetrate intact cell membranes, whereas propidium iodide passes solely damaged membranes and therefore displaces SYTO 9 in these cells and label them red. Micrographs of sclerotia were obtained by using a Leica TCS SPE confocal laser-scanning microscope (Leica Microsystems, Mannheim, Germany). The wavelengths of the excitation/ emission are at $480 / 500 \mathrm{~nm}$ for the green fluorescence and at 490/ $635 \mathrm{~nm}$ for the red fluorescence.

Treatment of sclerotia from $S$. sclerotiorum with alkylpyrazines. Volatile alkylpyrazines were used as model compounds to evaluate the antifungal effect of a compound group that was so far not known for its sclerotia-inhibiting effects. Therefore, $30 \mu \mathrm{l}$ of 2-ethylpyrazine (EP), 2,3-dimethyl-5-isobutylpyrazine (DMIBP; both obtained from Sigma Aldrich, Germany), or a mixture of both alkylpyrazines (2P) were transferred into a lid of a $15 \mathrm{ml}$ tube (Sarstedt, Germany), placed inside a petri dish containing 20 sclerotia and incubated for 7 days. In a second approach, an additional $30 \mu \mathrm{l}$ of the potentially bioactive alkylpyrazines was added after 7 days of incubation, resulting in an extended incubation time of 14 days. After 7 and 14 days, all sclerotia were collected and placed onto PDA plates. The germination of sclerotia was assessed after 72 and $96 \mathrm{~h}$.

Statistical analysis. Statistical analysis of the amplicon sequencing data were performed within the QIIME pipeline and the $\mathrm{R}$ environment. The statistical analysis for beta diversity significance was performed in QIIME 1.9.0 (PERMANOVA test) and R environment using the packages phyloseq v. 1.24.2 (McMurdie and Holmes 2013) and vegan v. 2.5-3 (Oksanen et al. 2018) with the Adonis test (999 permutations). Similarly, the assessment of differential abundance of distinct OTUs in the bacterial microbiome was calculated using the package DESeq2 (Love et al. 2014) by using an unrarefied OTU table filtered for OTUs accounting for $\geq 1 \%$ of the total read number and plotted using ggplot 2 package 
(Wickham 2016). In addition, Dunnett's test and ANOVA analysis was performed in $\mathrm{R}$ environment using the packages DescTools (Signorell 2015) and multcompView (Graves et al. 2015) to assess significance of treatment efficiency in volatile assays.

\section{RESULTS}

Bacterial communities associated with sclerotia of $\boldsymbol{R}$. solani. The community composition of macrosclerotia (MS) and microsclerotia (mS) of $R$. solani as well as potato tuber surface (Ts) and of surrounding soil (So) was analyzed with Illumina-based highthroughput sequencing. Analysis of the $16 \mathrm{~S}$ ribosomal RNA gene fragment amplicons revealed a high bacterial diversity across the samples. A total of 8,226 OTUs were identified at species level (97\% sequences identity) in a library that consisted of 14,328,349 quality filtered reads. Altogether, 37 bacterial families were detected with an average abundance of at least $0.5 \%$ among all samples (Supplementary Fig. S1). The predominant bacterial families across all samples were Sphingomonadaceae (macrosclerotia: 3.4 to $5.5 \%$, microsclerotia: 2.1 to $10.9 \%$, tuber surface: 4.2 to $15.6 \%$, and surrounding soil: 6.9 to $8.1 \%$ ) followed by Streptomycetaceae (macrosclerotia: 1.2 to $13.3 \%$, microsclerotia: 2.2 to $9.1 \%$, tuber surface: 1.3 to $6.2 \%$, and surrounding soil: 4.8 to $6.1 \%$ ), and Pseudonocardiaceae (macrosclerotia: 0.9 to $26.8 \%$, microsclerotia: 1.2 to $15.4 \%$, tuber surface: 0.6 to $12.8 \%$, and surrounding soil: 3.1 to $5.6 \%$ ). Network construction and Cytoscape-based (Shannon et al. 2003) rendering was used to represent the proportional abundance of OTUs in investigated habitats (Fig. 1). When the OTU distribution among samples was assessed, the highest number of unique OTUs was found in tuber surface samples (33 unique OTUs) followed by soil samples (12). One third (four OTUs) of the unique signatures in soil samples were assigned to the genus Bacillus. Different trends of the proportionate composition were detected at family level. Caulobacteraceae and Flavobacteriaceae were primarily found in tuber surface samples (51.8 and $52.4 \%$ of reads, respectively), whereas Bacillaceae showed higher relative abundance in surrounding soil samples (57.9\% of reads). Moreover, Micromonosporaceae, Methylophilaceae, and Anaerolineaceae were primarily represented in tuber surface samples (51.1, 52.5, and 55.9\%). Furthermore, Phyllobacteriaceae, Bradyrhizobiacae, Intrasporangiaceae, and Gaiellaceae were overrepresented in samples of macro- and microsclerotia (approximately $70 \%$ of reads). A complementary analysis of differential abundance of OTUs with the DESeq2 algorithm resulted in the identification of various taxa that were either prevalent in sclerotia or the tuber surface (Supplementary Fig. S2). The genera Nonomuraea, Kribbella, and Taibaiella revealed a higher relative abundance in sclerotia (macro- and microsclerotia) in comparison with the potato tuber surface. Caulobacter and Flavobacterium were significantly more abundant in tuber surface samples. Habitat-specific alpha diversity analysis, based on a nonparametric two-sample $t$ test, revealed significant differences regarding species richness among habitats tuber surface and surrounding soil $(P=0.036)$ and tuber surface and macrosclerotia $(P=$ 0.006) (Supplementary Fig. S3). Beta diversity analysis showed significant differences among the four sample types $\left(R^{2}=0.26484, \operatorname{Pr}\right.$ $(>\mathrm{F})=0.001)$ and a similarity of tuber surface samples with soil samples when visualized in a PCoA plot (Supplementary Fig. S4). Additionally, a PERMANOVA analysis was employed to weight the significance of intersample differences. It revealed that the tuber surface and the surrounding soil harbor distinct bacterial microbiomes (Ts versus So, $P=0.003$; Ts versus MS, $P=0.001$; Ts versus $\mathrm{mS}, P=0.001$; So versus MS, $P=0.002$, So versus $\mathrm{mS}, P=0.009$ ). In contrast, no significant differences in the community structure were found for samples derived from micro- and macrosclerotia $(P=$ $0.351)$.

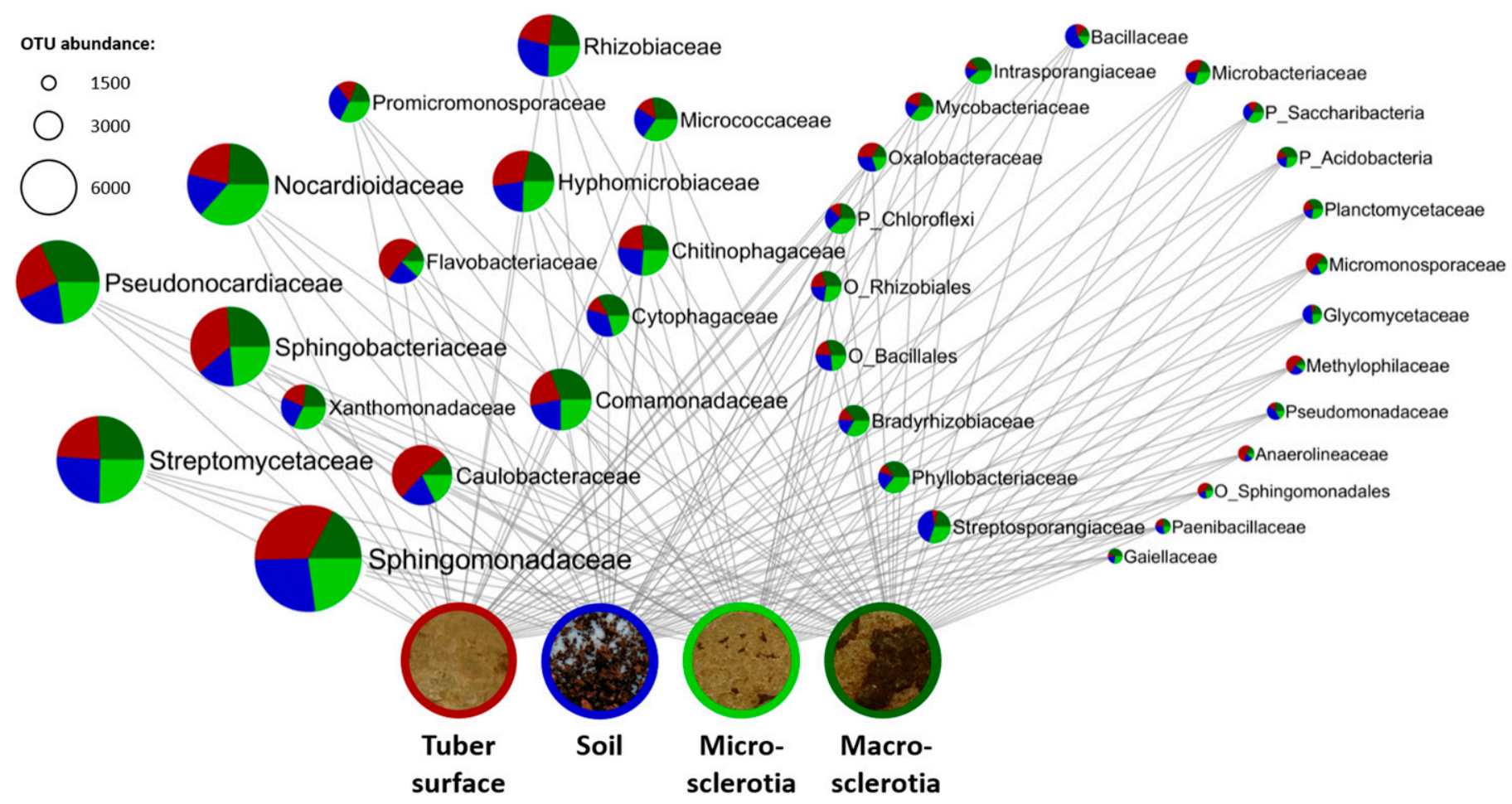

Fig. 1. Bacterial community composition on family level of different habitats obtained from Rhizoctonia solani-infected potatoes. A network was constructed in order to identify habitat-specific signatures. The node size represents the total amount of reads of the respective operational taxonomic unit (OTU). Pie charts indicate the relative amount of reads for each of the four habitats. Only OTUs with a relative abundance of at least $0.5 \%$ across all samples are considered. 
Screening for potential antagonists - combination of volatileproducing bacteria to develop biocontrol consortia. An initial screening for antifungal traits of 560 sclerotia-associated bacterial strains resulted in a collection of 47 antagonistic isolates (a detailed overview of the conducted experiments is shown in Supplementary Fig. S5). These bacteria were able to inhibit the mycelial growth of $S$. sclerotiorum and/or $R$. solani in dual culture assays. Less than one third (13/47) of these preselected antagonistic isolates originated from the initial 400 bacterial strains obtained from $R$. solani-infected potato tubers. The majority of the 13 bacterial antagonists was isolated from macrosclerotia (RsMS14, Rs-MS28, Rs-MS53, Rs-MS84, and Rs-MS87), only one from microsclerotia (Rs-mS115), four from the unaffected tuber surface (Rs-Ts222, Rs-Ts259, Rs-Ts269, and Rs-Ts276), and the remaining from the surrounding soil (Rs-So360, Rs-So365, and Rs-So386). In parallel, 160 bacterial strains were isolated via the $S$. sclerotiorum bait system. This led to the identification of 34 (21.25\% of all bait system isolates) isolates with antagonistic properties (Supplementary Table S2). The largest proportion of these 34 bacterial isolates associated with Sclerotinia sclerotiorum originated from sclerotia buried in compost (12), followed by sclerotia from beech forest soil (8), and sclerotia buried in sandy soil and peat (7 each). Almost all cultivated antagonistic isolates (41 of 47) were assigned to the genus Bacillus. The genera Buttiauxella, Enterobacter, and Pseudomonas were represented by two isolates each.

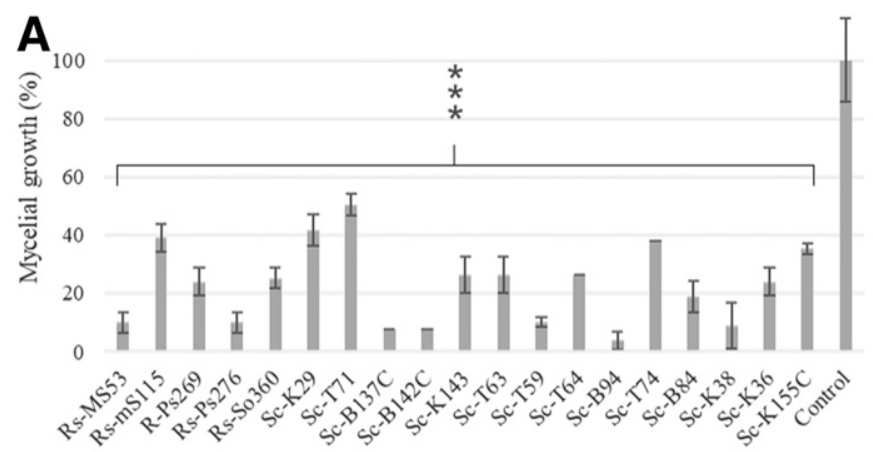

Isolates

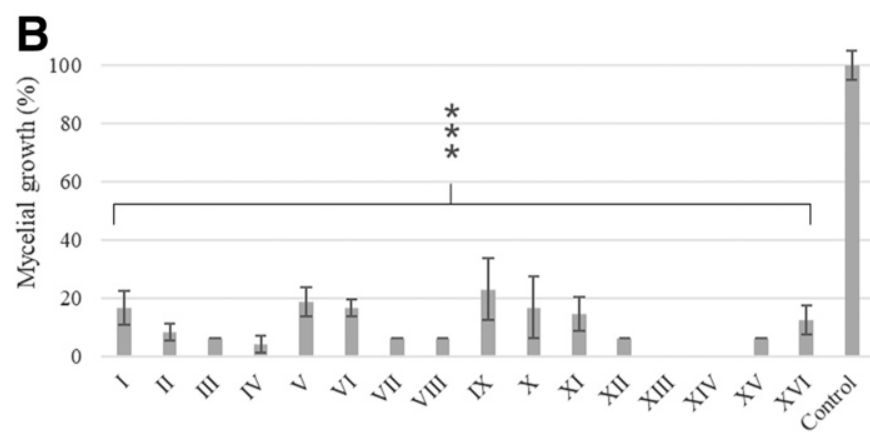

Twosome consortia

Fig. 2. Inhibition of mycelial growth of Sclerotinia sclerotiorum of different isolates via microbial volatile organic compounds (mVOCs). Effects of mVOCs emitted by antagonistic bacteria on the growth of plantpathogenic fungi were evaluated with Petri dish VOCs assay (PDVA) experiments. The control (PDA plate with mycelium; NA without bacteria) was set to $100 \%$. A, Application of single bacteria. All isolates were assigned to the genus Bacillus with the exception of the isolates Sc-T74 (genus Buttiauxella) and Sc-B94 (genus Pseudomonas). B, Combination of two isolates as bacterial consortia. Dunnett's test confirmed a highly significant decrease of mycelial growth in comparison with the control $\left({ }^{*}=P \leq 0.05 ;{ }^{* *}=P \leq 0.01\right.$; and $\left.{ }^{* *}=P \leq 0.001\right)$.
The antagonistic isolates from both isolation sources (47 isolates) were further tested in terms of their potential to suppress mycelial growth of both fungi via the production of bioactive volatiles. In the conducted mVOC assays, $S$. sclerotiorum was considerably more vulnerable to volatiles from isolates of both approaches: the 19 most effective antagonists revealed a growth inhibition of 49.6 to $96.2 \%$, while the mycelium of $R$. solani was reduced no more than $33.6 \%$ (Figs. 2 and 3).

Isolates revealing the antagonistic effects via volatile production were randomly combined to augment the effect on each of the two

A

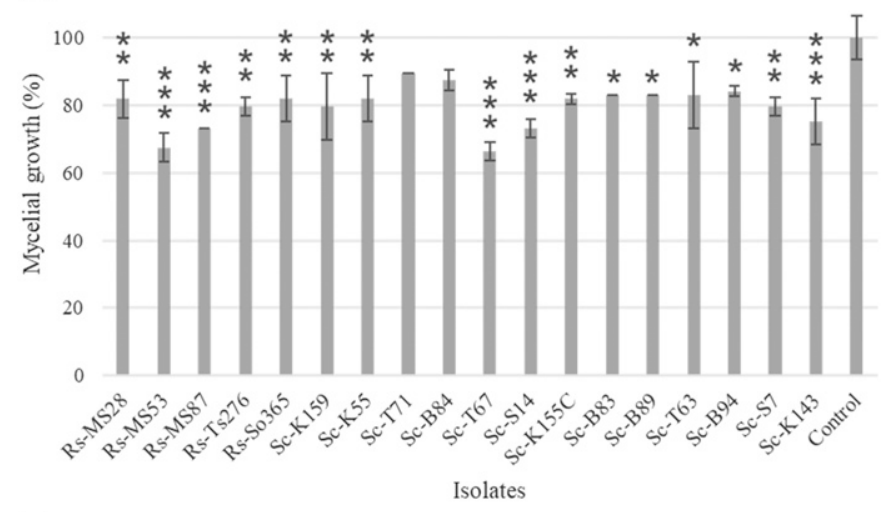

B
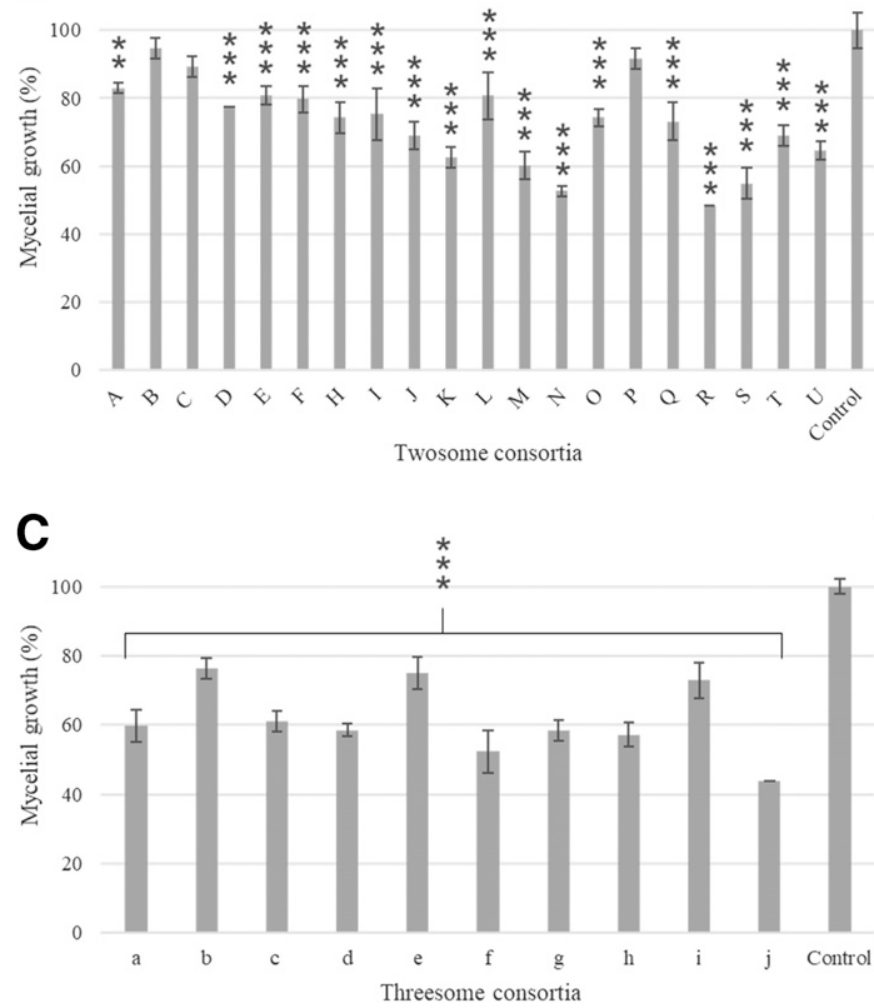

Fig. 3. Inhibition of mycelial growth of Rhizoctonia solani of different isolates via microbial volatile organic compounds (mVOCs). The growth reduction of the plant pathogenic fungus was evaluated with Petri dish VOCs assay (PDVA) experiments. The control (PDA plate with mycelium; NA without bacteria) was set to $100 \%$. A, Application of single bacteria. All isolates were assigned to the genus Bacillus with the exception of isolate Sc-B94 (genus Pseudomonas). B, Combination of two isolates as bacterial consortia. C, Combination of three bacteria as consortia. Dunnett's test confirmed a significant decrease of mycelial growth in comparison with the control ${ }^{*}=P \leq 0.05 ;{ }^{* *}=P \leq 0.01$; and $\left.{ }^{* \star *}=P \leq 0.001\right)$. 
phytopathogenic fungi used in the assays (Supplementary Table S3). Assembled consortia with different isolates enhanced the antifungal activity significantly. Distinct combinations of antagonists resulted in a complete inhibition of mycelial growth of $S$. sclerotiorum and an increased impact on $R$. solani with a $51.6 \%$ reduction in twosome and $56.2 \%$ in threesome consortia (Figs. 2 and 3). $R$. solani revealed to be more sensitive to mVOCs of Bacillus isolates. The strongest inhibition in single isolate assays was caused by B. cereus Sc-T67. Twosome and threesome consortia of Bacillus spp. (consortium R [B. cereus Rs-MS53+ B. amyloliquefaciens Sc-K143]; consortium j [B. cereus RsMS53 + B. aerius Rs-So365 + B. amyloliquefaciens Sc-K55]) had the highest impact on the mycelium of $R$. solani. On the contrary, volatiles emitted by Pseudomonas helmanticensis ScB94 restrained mycelial growth of $S$. sclerotiorum most effectively $(96.2 \%)$. The antagonistic activity peaked in total growth inhibition caused by the consortium XIV consisting of the Pseudomonas strain in combination with B. cereus Rs-MS53.

mVOCs alter the morphology of exposed sclerotia. Treatments of sclerotia of $S$. sclerotiorum with $\mathrm{mVOCs}$ over a period of 27 days resulted in a visible alteration of the morphology and an increased production of clear aqueous fluids. The preselected bacterial antagonists of S. sclerotiorum altered the hard, resilient texture of the survival structures substantially. Volatiles of Buttiauxella warmboldiae, P. helmanticensis, and Bacillus consortia intenerated the sclerotial tissue. The substantial effects were visualized with crosssections mVOCs-treated sclerotia (Fig. 4). While controls of untreated sclerotia and treatments with $E$. coli K-12 revealed the typical light gray inner texture of compact fungal mycelium, treatments with Bacillus consortia, P. helmanticensis Sc-B94 and Buttiauxella warmboldiae Sc-T74 resulted in discolorations of the inner sclerotial tissue. When the treated sclerotia were incubated on PDA plates, no significant effect on their germination ability was observed (data not shown).

Confocal laser scanning microscopy of long-term treated sclerotia. After identification of morphological changes of sclerotia following the treatment with bacterial volatiles, the viability of the hyphae was analyzed. Confocal laser scanning microscopy combined with differential staining revealed layers of damaged and intact hyphae. Cross-sections of controls of untreated sclerotia and treatments with E. coli K-12 featured an outside layer, commonly filled with melanin, of nonviable hyphae with a diameter of 40 to $60 \mu \mathrm{m}$ (Fig. 5). Bacterial volatiles produced by P. helmanticensis Sc-B94 and Buttiauxella warmboldiae Sc-T74 increased this layer to $>200$ and $>130 \mu \mathrm{m}$, respectively. Nevertheless, the core of the medulla, the interior portion of sclerotia, remained viable after the treatment.

Mass-spectrometric identification of bioactive mVOCs. The volatilome of several potential biocontrol agents was analyzed for a possible association of compounds to the inhibitory effects on $R$. solani and S. sclerotiorum. B. amyloliquefaciens Sc-K143, B. cereus Rs-MS53, B. amyloliquefaciens Sc-K55, B. cereus RsMS53, B. aerius Rs-So365, and P. helmanticensis Sc-B94 were selected due to their emergence as compelling antagonists. A total of 41 different microbial volatiles were identified and matched to substances in the NIST MS Database 14 after sampling the headspace with two SPME fibers with defined coatings. A total of 22 compounds were identified in headspace analyses with both fibers, while 16 were solely detectable with a fiber coating consisting of DVB/ CAR/PDMS and 3 that were exclusively detected with the PDMS/ DVB coating (Table 1). A high proportion of volatile alcohols, alkanes, ketones organic acids, and sulfides were detected. Ketones were identified as volatiles with the highest frequency among the different isolates. Alkylated pyrazines were less common and mainly produced by B. cereus Rs-MS53 and B. aerius Rs-So365. The emission of dimethyl sulfide and 1-undecene differentiated $P$. helmanticensis Sc-B94 from other isolates assigned to the genus Bacillus. There was no mVOC shared among all five strains while several substances were produced by only one bacterial strain. A considerable amount of bacterial VOCs could not be classified due to missing database matches in the utilized NIST 14 MS database.

Alkylpyrazines affect the germination of sclerotia of $S$. sclerotiorum. The exposure of sclerotia to mVOCs of the bacterial isolates in confrontation assays was not followed by significant reductions of their viability. Therefore, an identified compound group that was prevalent in the mVOC profiles was selected to explore the potential of analogous synthetic compounds to inhibit the highly resistive structures. Sclerotia of $S$. sclerotiorum were exposed to the volatile alkylpyrazines 2-ethylpyrazine (EP) and 2,3-dimethyl-5-isobutylpyrazine (DMIBP) as single substances and in a combined treatment with both pyrazines (2P). When EP and $2 \mathrm{P}$ were applied, a significant reduction of the sclerotial germination rates was observed after $96 \mathrm{~h}$ of incubation on PDA plates
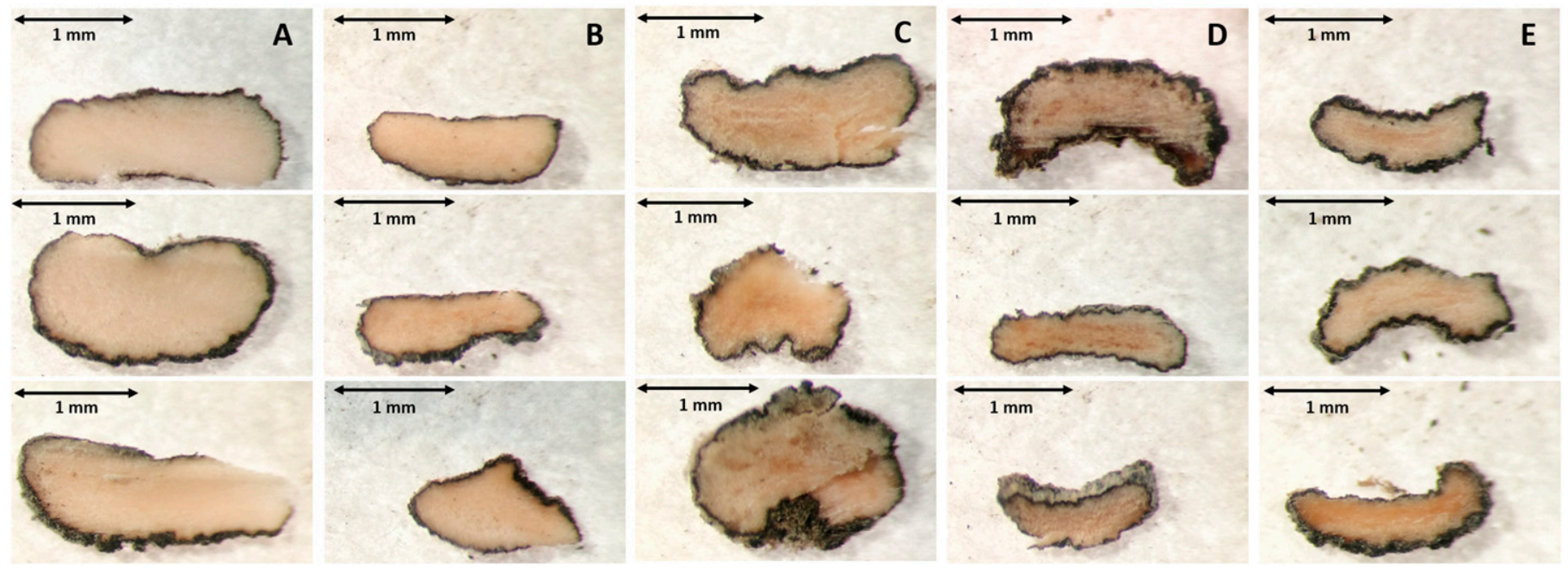

Fig. 4. Macrographs of sclerotia of Sclerotinia sclerotiorum. Cross-sections of sclerotia that were exposed to microbial volatile organic compounds for 27 days were obtained for comparative assessments. A, Untreated sclerotia. Treatments of sclerotia with B, Escherichia coli K-12; C, Bacillus cereus Rs-MS53/Bacillus aerius Rs-So360; D, Pseudomonas helmanticensis Sc-B94; and E, Buttiauxella warmboldiae Sc-T74. 
(Supplementary Fig. S6). Both of the two alkylpyrazines, as well as the combination, significantly decreased the germination rate in an approach with a second application after 7 days.

\section{DISCUSSION}

Fungal survival structures were shown to harbor specific microbial fingerprints that differentiate them from microbial communities in their surroundings. Moreover, we found that they are associated with specific antagonists, which can substantially suppress mycelium growth of the fungal pathogens. The production of mVOCs by bacterial antagonists, especially by combinations of them, was identified as a major mechanism of antagonism. Application of an identified compound class that was so far not known for bioactive effects against sclerotia confirmed the mVOCs-based inhibition potential. Bacterial antagonists which affected fungal growth, sclerotia formation and survival, provide a promising basis for the development of biocontrol agents to control soilborne fungal pathogens under field conditions.

The assessment of the sclerotia microbiome and its differences to the unaffected tuber surface of potatoes led to the identification of bacteria that potentially interact with $R$. solani. Our observations primarily reflect habitat-specific enrichments of distinct bacterial taxa that are driven by differing occurrence of $R$. solani, because it was likely also present in its mycelial form in the seemingly unaffected samples. The dominant phylum in all four sample types
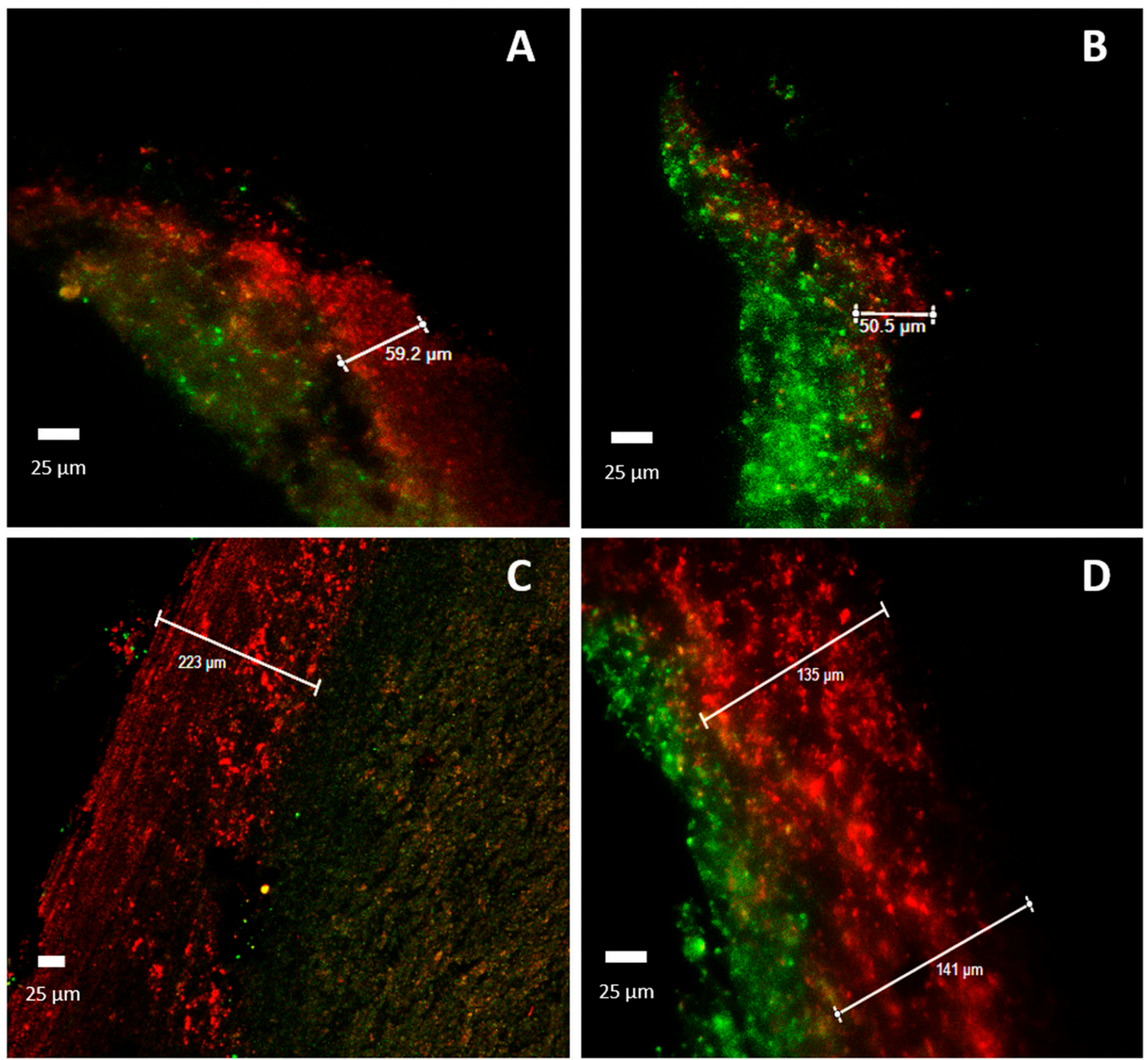

Fig. 5. Micrographs of differentially stained sclerotia cross-sections. The effects of microbial volatile organic compound exposure on the viability of sclerotia of Sclerotinia sclerotiorum were evaluated in a microscopy-based approach. Green indicates intact hyphae; and red indicates damaged hyphae. A and B, Untreated sclerotia; C, Sclerotia treated with Pseudomonas helmanticensis Sc-B94; and D, Sclerotia treated with Buttiauxella warmboldiae Sc-T74. 
was assigned to Proteobacteria as previously shown with other potato cultivars (Weinert et al. 2011). In another related study, Alphaproteobacteria were together with Actinobacteria the most common bacterial colonizers of the potato rhizosphere (Inceoğlu et al. 2011; Weinert et al. 2011). This predominant class Proteobacteria comprises the bacterial family Caulobacteraceae, which were, along with Flavobacteriaceae, enriched on the sclerotia-free tuber surface. Species of Caulobacteraceae and Flavobacteriaceae such as Brevundimonas diminuta NBRI012 and Flavobacterium were shown to possess plant-beneficial properties (Singh et al. 2015; Soltani et al. 2010). Further families that had a higher relative abundance in samples of tuber surface were Micromonosporaceae, Methylophilaceae, and Anaerolineaceae, which so far could not be linked to any plant-beneficial effects. The augmented abundance of these potential biomarkers for unaffected tuber surfaces could correlate with the prevention of sclerotia formation. In contrast to the other habitats, Bradyrhizobiaceae, Phyllobacteriaceae, Intrasporangiaceae, and Gaiellaceae were located primarily in macroand microsclerotia. Donn et al. (2014) showed a high abundance of Bradyrhizobiaceae in soil to be conductive to the proliferation of $R$. solani AG-8. These possible bacterial biomarkers of the AG-8 sclerotial microbiome could interrelate with a beginning $R$. solani infection and the cohering formation of sclerotia. The implications of most of these bacterial families in disease development is yet unexplained and modes of interactions of the microbiome of the geocaulosphere, the rhizosphere, and the bulk soil require further

TABLE 1

Volatiles produced by different bacterial isolates ${ }^{a}$

\begin{tabular}{|c|c|c|c|c|c|c|c|c|}
\hline \multirow[b]{2}{*}{ Compound } & \multirow[b]{2}{*}{$\begin{array}{l}\text { Kovats } \\
\text { index }\end{array}$} & \multicolumn{5}{|c|}{ Bacterial isolates } & \multirow[b]{2}{*}{ Biological function } & \multirow[b]{2}{*}{ Reference } \\
\hline & & $\begin{array}{l}\text { Rs- } \\
\text { MS53 }\end{array}$ & $\begin{array}{l}\text { Rs- } \\
\text { So365 }\end{array}$ & $\begin{array}{l}\text { Sc- } \\
\text { B94 }\end{array}$ & $\begin{array}{l}\text { Sc- } \\
\mathrm{K} 143\end{array}$ & $\begin{array}{l}\mathrm{Sc}- \\
\mathrm{K} 55\end{array}$ & & \\
\hline Methanethiol $^{\mathrm{b}}$ & 401 & $\Delta$ & & $\Delta$ & $\leq$ & $\Delta$ & n.a. & \\
\hline Isoprene $^{\mathrm{b}}$ & 510 & & & & - & - & $\begin{array}{l}\text { Protection against heat } \\
\text { stress, stabilizes cell } \\
\text { membranes in response to } \\
\text { heat stress, bacterial } \\
\text { interactions }\end{array}$ & Tyc et al. 2017; Wilkins 1996 \\
\hline Dimethyl sulfide $^{b}$ & 518 & & & $\Delta$ & & & n.a. & \\
\hline 2-Methylfuran ${ }^{b}$ & 611 & & - & & & & Bacterial interactions & Tyc et al. 2017 \\
\hline 2,3-Butanedione ${ }^{b}$ & 651 & & & $\leq$ & $\Delta$ & $\leq$ & n.a. & \\
\hline 2,3,4-Trimethyloxetane & 655 & & $\Delta$ & & & & n.a. & \\
\hline 1-Chlorobutane & 656 & $\Delta$ & & - & & & n.a. & \\
\hline 2-Pentanone ${ }^{b}$ & 684 & & & - & - & - & Nematicidal activity & Xu et al. 2015 \\
\hline Methylthioacetate & 697 & $\Delta$ & & $\Delta$ & & & n.a. & \\
\hline Acetoin $^{a}$ & 708 & $\leq$ & $\leq$ & & - & - & $\begin{array}{l}\text { Mediates plant-beneficial } \\
\text { effects such as growth } \\
\text { promotion and systemic } \\
\text { resistance (ISR) in model } \\
\text { plants and crops under in } \\
\text { vitro and in situ conditions }\end{array}$ & $\begin{array}{l}\text { Hahm et al. 2012; Han et al. } \\
\text { 2006; Ryu et al., } 2003\end{array}$ \\
\hline 3-Methylbutanenitrile & 722 & - & & & & & n.a. & \\
\hline 3-Methyl-1-butanol ${ }^{\mathrm{b}}$ & 725 & - & & & $\boldsymbol{\Delta}$ & $\boldsymbol{\Delta}$ & $\begin{array}{l}\text { Complete inhibition of } \\
\text { mycelial growth of } \\
\text { Phyllosticta citricarpa }\end{array}$ & Toffano et al. 2017 \\
\hline 1-Chloropentane & 725 & & - & & & & n.a. & \\
\hline 2-Methyl-1-butanol ${ }^{\mathrm{b}}$ & 728 & & - & & & & $\begin{array}{l}\text { Weakly active against wood- } \\
\text { decaying fungi }\end{array}$ & Schulz and Dickschat, 2007 \\
\hline 1-(3-Methyloxiranyl)-ethanone & 728 & & & & & - & n.a. & \\
\hline Dimethyl disulfide ${ }^{b}$ & 733 & $\Delta$ & & $\Delta$ & $\Delta$ & $\Delta$ & $\begin{array}{l}\text { Antagonistic effect against } \\
\text { sapstain fungi, nematicidal } \\
\text { activity, and reduces } \\
\text { mycelium growth and } \\
\text { sclerotia germination of } \\
\text { Sclerotinia sclerotiorum }\end{array}$ & $\begin{array}{l}\text { Giorgio et al. 2015; Schulz and } \\
\text { Dickschat, 2007; Xu et al. } \\
2015\end{array}$ \\
\hline Dimethyl sulfone $^{b}$ & 733 & & - & & - & - & n.a. & \\
\hline 3-Methyl-2-pentanone ${ }^{b}$ & 741 & & - & & $\Delta$ & $\Delta$ & n.a. & \\
\hline \multirow[t]{2}{*}{ 3-Methoxy-3-methyl-2-butanone } & 758 & - & - & & & - & n.a. & \\
\hline & & & & & & & & (Continued on next page) \\
\hline \multicolumn{9}{|c|}{$\begin{array}{l}\text { adentification was performed via headspace-solid phase microextraction (HS-SPME) gas chromatography-mass spectrometry (GC-MS), matching to } \\
\text { the NIST Mass Spectral Database and confirmation by the Kovats index. } \\
\text { bs Asignment as microbial volatile organic compounds (mVOCs) refers to the presence in the mVOC database (Lemfack et al. } 2018) ;-=\text { solely } \\
\text { identified with fiber divinylbenzene/carboxen/polydimethylsiloxane (DVB/CAR/PDMS); } \leq=\text { only identified with fiber polydimethylsiloxane/ } \\
\text { divinylbenzene (PDMS/DVB); and } \boldsymbol{\Delta}=\text { identified with both fibers. }\end{array}$} \\
\hline
\end{tabular}


research. The unaffected tuber surface harbored the lowest bacterial diversity, implying that potato plants gather a specific microbiome.

In addition, the sclerotia-associated bacterial microbiome was shown to be a potential source for biocontrol agents which, in specific combinations revealed exceeding capability. The bait system described by Zachow et al. (2011) provides a wellfunctioning accumulation method of antagonistic bacteria with $21.25 \%$ of all isolates exhibiting antifungal traits in comparison with only $3 \%$ by sampling infected potato tubers. The important role of interspecies interactions of bacteria in the accumulation of antibiotics has been emphasized in previous studies (Garbeva et al. 2011; Seyedsayamdost et al. 2012). Garbeva et al. (2011) observed that the assembly of antimicrobial metabolites of $P$. fluorescens Pf0-1 was enhanced by Brevundimonas and Pedobacter, but not Bacillus. In the present study, experiments of volatile confrontation exhibited an increased antagonistic effect against $S$. sclerotiorum when combining B. cereus Rs-MS53 and P. helmanticensis Sc-B94. This is most likely due to strain-specific compatibility. As already observed by Zachow et al. (2011), the majority of isolates with antagonistic properties toward sclerotia-forming fungi were assigned to the genus Bacillus. Biological control mechanisms of Bacillus spp. and Pseudomonas spp. have been investigated in a vast number of surveys (Ait-Lahsen et al. 2001; Asari et al. 2016; Hong and Meng 2003; Lim et al. 1991; Peighami-Ashnaei et al.

TABLE 1 (Continued from previous page)

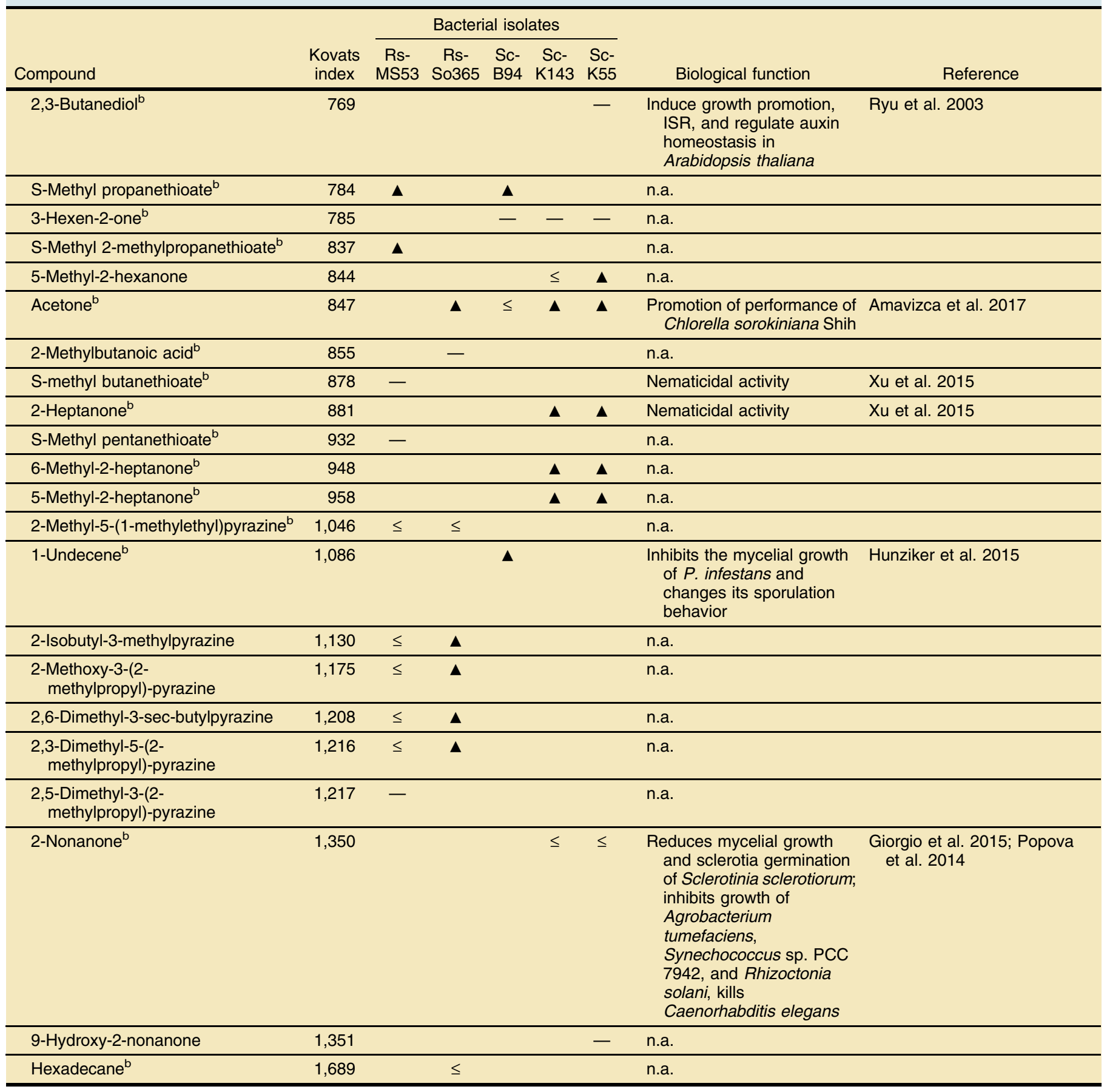


2009) and the potential of consortia for biological control was predicted many years ago (Dowling and O'Gara 1994). However, this study is, to our knowledge, the first to demonstrate the augmented effect of mVOCs of bacterial consortia. The composition of bacterial consortia plays a crucial role in terms of the observed effects and requires a detailed assessment of the possible combinations. Similar to observations of Tyc et al. (2014) concerning nonvolatile secondary metabolites, combinations of bacteria could result in both increasing and decreasing of antimicrobial volatile activity. Disturbance of signal transduction pathways, e.g., quorum sensing, was stated as source for the decline of antimicrobial activity in the quorum sensing system (Christensen et al. 2013; Gonzalez and Keshavan 2006). Mechanisms of enhanced sensitivity of phytopathogenic fungi to mVOCs are still unexplained and require additional research. Further observations could facilitate the establishing of microbial consortia to form a "minimal microbiome" for specific ecosystem services such as the biological control of soilborne diseases (Mendes et al. 2013). Moreover, a better understanding of the plant microbiome appears to be crucial to prevent the outbreak of plant diseases; thus, the importance plant-associated microorganisms will increase in the fields of plant breeding and biotechnology (Berg et al. 2014).

Microbial volatiles proved to be essential mediators for antagonistic interactions and local defense in various microniches (Cernava et al. 2015) as well as for cross-kingdom interactions with fungi, plants, and nematodes (Létoffé et al. 2014). Schulz-Bohm et al. (2018) emphasized the significance of VOCs in belowground interactions by revealing that plants, bacteria, and pathogenic fungi can communicate over long distances in soil. Thereby, they also showed that various volatiles are able to disperse over more than $12 \mathrm{~cm}$ in soil. According to the mVOC database (Lemfack et al. 2018), 13 of 41 compounds released by B. amyloliquefaciens ScK143, B. cereus Rs-MS53, B. amyloliquefaciens Sc-K55, B. cereus Rs-MS53, B. aerius Rs-So365, and P. helmanticensis Sc-B94 have not been identified as microbial volatiles before and the biological function is only known for 13 out of 28 previously described mVOCs. Two of the most prominent bacterial volatile substances known for a plant beneficial effect are acetoin and 2,3-butanediol, which enhance growth and trigger induced systemic resistance of Arabidopsis thaliana against $P$. syringae DC3000 (Rudrappa et al. 2010; Ryu 2004; Ryu et al. 2003). It has been shown that dimethyl disulfide has a role in plant protection and inhibits the growth of plant-pathogenic fungi and nematodes (Coosemans 2005; Kai et al. 2009). Similarly, 3-methyl-1-butanol is able to completely suppress the mycelial growth, germination, and appressorium formation by conidia of Phyllosticta citricarpa (Toffano et al. 2017). CLSM micrographs obtained after long-term exposure to bacterial VOCs revealed a damage of sclerotial hyphae in outer layers while medullar mycelium remained intact. This is in accordance to the study of Giorgio et al. (2015), where fungistatic effects of mVOCs on sclerotia were observed. Nevertheless, observations of Cernava et al. (2015), Minerdi et al. (2009), and Spence et al. (2014) that mVOCs can significantly decrease mycelial viability of fungal plant pathogens were confirmed. In contrast to volatiles produced by the antagonistic strains in the confrontation assay, the alkylpyrazines 2ethylpyrazine and 2,3-dimethyl-5-isobutylpyrazine, when applied as pure compounds, significantly inhibited the germination rate of the exposed sclerotia of $S$. sclerotiorum. This could be explained by an insufficient amount of naturally produced bacterial volatiles to completely inactivate the viability of sclerotia under the tested cultivation conditions. Bacteria were shown to produce antifungal volatiles, which make them less susceptible to mycoparasites such as Coniothyrium minitans and Trichoderma spp. (Jones et al. 2014). However, the emitted concentrations might not be sufficient to cause further damage than required for their protection. Understanding the complex interactions mediated by mVOCs will be the key to finding suitable tools for crop protection to aim for sustainable agriculture (Kanchiswamy et al. 2015).

In conclusion, $R$. solani proved to be an ideal model to extend present knowledge about sclerotia-associated bacteria that potentially correlate with the formation of these survival structures on potatoes. Complementary experiments with the larger sclerotia of S. sclerotiorum revealed that volatiles can alter the morphology of sclerotia and increase the layer of nonviable hyphae. We provided evidence for a boosted antifungal effect of bacterial consortia via $\mathrm{mVOCs}$ and identified novel microbial volatiles. We suggest further research to gather deeper insights on the role of bacteria in preventing or assisting phytopathogenic fungal infections and the investigation of bacterial consortia as advanced biocontrol agents.

\section{LITERATURE CITED}

Ait-Lahsen, H., Soler, A. S., Rey, M., De, J. S., Cruz, L., Monte, E., and Llobell, A. 2001. An antifungal exo- $\alpha$-1,3-glucanase (AGN13.1) from the biocontrol fungus Trichoderma harzianum. Appl. Environ. Microbiol. 67:5833-5839.

Allan, E., Van Ruijven, J., and Crawley, M. J. 2010. Foliar fungal pathogens and grassland biodiversity. Ecology 91:2572-2582.

Amavizca, E., Bashan, Y., Ryu, C.-M., Farag, M. A., Bebout, B. M., and DeBashan, L. E. 2017. Enhanced performance of the microalga Chlorella sorokiniana remotely induced by the plant growth-promoting bacteria Azospirillum brasilense and Bacillus pumilus. Sci. Rep. 7:41310.

Asari, S., Matzén, S., Petersen, M. A., Bejai, S., and Meijer, J. 2016. Multiple effects of Bacillus amyloliquefaciens volatile compounds: Plant growth promotion and growth inhibition of phytopathogens. FEMS Microbiol. Ecol. 92:1-11.

Berendsen, R. L., Pieterse, C. M. J., and Bakker, P. A. H. M. 2012. The rhizosphere microbiome and plant health. Trends Plant Sci. 17:478-486.

Berg, G., Grube, M., Schloter, M., Smalla, K., Leveau, J., Vorholt, J., and Lindow, S. E. 2014. Unraveling the plant microbiome: Looking back and future perspectives. Front. Microbiol. 5:148.

Berg, G., Roskot, N., Steidle, A., Eberl, L., Zock, A., and Smalla, K. 2002. Plantdependent genotypic and phenotypic diversity of antagonistic rhizobacteria isolated from different Verticillium host plants. Appl. Environ. Microbiol. 68: 3328-3338.

Berg, G., Rybakova, D., Grube, M., and Köberl, M. 2016. The plant microbiome explored: Implications for experimental botany. J. Exp. Bot. 67:995-1002.

Berg, G., Zachow, C., Müller, H., Philipps, J., and Tilcher, R. 2013. Nextgeneration bio-products sowing the seeds of success for sustainable agriculture. Agronomy (Basel) 3:648-656.

Burr, T. J., Schroth, M. N., and Suslow, T. 1978. Increased potato yields by treatment of seed pieces with specific strains of Pseudomonas fluorescens and P. putida. Phytopathology 68:1377-1383.

Caporaso, J. G., Kuczynski, J., Stombaugh, J., Bittinger, K., Bushman, F. D., Costello, E. K., Fierer, N., Pẽa, A. G., Goodrich, J. K., Gordon, J. I., Huttley, G. A., Kelley, S. T., Knights, D., Koenig, J. E., Ley, R. E., Lozupone, C. A., McDonald, D., Muegge, B. D., Pirrung, M., Reeder, J., Sevinsky, J. R., Turnbaugh, P. J., Walters, W. A., Widmann, J., Yatsunenko, T., Zaneveld, J., and Knight, R. 2010. QIIME allows analysis of high-throughput community sequencing data. Nat. Methods 7:335-336.

Caporaso, J. G., Lauber, C. L., Walters, W. A., Berg-Lyons, D., Lozupone, C. A., Turnbaugh, P. J., Fierer, N., and Knight, R. 2011. Global patterns of $16 \mathrm{~S}$ rRNA diversity at a depth of millions of sequences per sample. Proc. Natl. Acad. Sci. 108:4516-4522.

Cernava, T., Aschenbrenner, I. A., Grube, M., Liebminger, S., and Berg, G. 2015. A novel assay for the detection of bioactive volatiles evaluated by screening of lichen-associated bacteria. Front. Microbiol. 6:1-9.

Christensen, L. D., van Gennip, M., Rybtke, M. T., Wu, H., Chiang, W. C., Alhede, M., Høiby, N., Nielsen, T. E., Givskov, M., and Tolker-Nielsena, T. 2013. Clearance of Pseudomonas aeruginosa foreign-body biofilm infections through reduction of the cyclic di-gmp level in the bacteria. Infect. Immun. $81: 2705-2713$.

Coosemans, J. 2005. Dimethyl disulphide (DMDS): A potential novel nematicide and soil disinfectant. Acta Hortic. 698:57-64.

Davis, J. R., Pavek, J. J., Corsini, D. L., Sorenson, L. H., Schneider, A. T., Everson, D. O., Westermann, D. T., and Huisman, O. C. 1994. Influence of continuous cropping of several potato clones on the epidemiology of Verticillium wilt of potato. Phytopathology 84:207-214. 
Donn, S., Almario, J., Muller, D., Moënne-Loccoz, Y., Gupta, V. V. S. R. Kirkegaard, J. A., and Richardson, A. E. 2014. Rhizosphere microbial communities associated with Rhizoctonia damage at the field and disease patch scale. Appl. Soil Ecol. 78:37-47.

Dowling, D. N., and O'Gara, F. 1994. Metabolites of Pseudomonas involved in the biocontrol of plant disease. Trends Biotechnol. 12:133-141.

Frank, J. A., Reich, C. I., Sharma, S., Weisbaum, J. S., Wilson, B. A., and Olsen, G. J. 2008. Critical evaluation of two primers commonly used for amplification of bacterial 16S rRNA genes. Appl. Environ. Microbiol. 74:2461-2470.

Frey-Klett, P., Burlinson, P., Deveau, A., Barret, M., Tarkka, M., and Sarniguet, A. 2011. Bacterial-fungal interactions: Hyphens between agricultural, clinical, environmental, and food microbiologists. Microbiol. Mol. Biol. Rev. 75:583-609.

Garbeva, P., Silby, M. W., Raaijmakers, J. M., Levy, S. B., and De Boer, W. 2011. Transcriptional and antagonistic responses of Pseudomonas fluorescens Pf0-1 to phylogenetically different bacterial competitors. ISME J. 5:973-985.

Giorgio, A., De Stradis, A., Lo Cantore, P., and Iacobellis, N. S. 2015. Biocide effects of volatile organic compounds produced by potential biocontrol rhizobacteria on Sclerotinia sclerotiorum. Front. Microbiol. 6:1-13.

Gonzalez, J. E., and Keshavan, N. D. 2006. Messing with bacterial quorum sensing. Microbiol. Mol. Biol. Rev. 70:859-875.

Graves, S., Piepho, H.-P., and Selzer, L. 2015. multcompView: Visualizations of Paired Comparisons. R package version 0.1-7. https://cran.r-project.org/web/ packages/multcompView/index.html

Grosch, R., Faltin, F., Lottmann, J., Kofoet, A., and Berg, G. 2005. Effectiveness of 3 antagonistic bacterial isolates to control Rhizoctonia solani Kühn on lettuce and potato. Can. J. Microbiol. 51:345-353.

Haas, D., and Défago, G. 2005. Biological control of soil-borne pathogens by fluorescent pseudomonads. Nat. Rev. Microbiol. 3:307-319.

Hahm, M. S., Sumayo, M., Hwang, Y. J., Jeon, S. A., Park, S. J., Lee, J. Y., Ahn, J. H., Kim, B. S., Ryu, C. M., and Ghim, S. Y. 2012. Biological control and plant growth promoting capacity of rhizobacteria on pepper under greenhouse and field conditions. J. Microbiol. 50:380-385.

Han, S. H., Lee, S. J., Moon, J. H., Park, K. H., Yang, K. Y., Cho, B. H., Kim, K. Y., Kim, Y. W., Lee, M. C., Anderson, A. J., and Kim, Y. C. 2006. GacSdependent production of 2R, 3R-Butanediol by Pseudomonas chlororaphis O6 is a major determinant for eliciting systemic resistance against Erwinia carotovora but not against Pseudomonas syringae pv. tabaci in tobacco. Mol. Plant-Microbe Interact. 19:924-930.

Hong, T.-Y., and Meng, M. 2003. Biochemical characterization and antifungal activity of an endo-1,3-b-glucanase of Paenibacillus sp. isolated from garden soil. Appl. Microbiol. Biotechnol. 61:472-478.

Hunziker, L., Bönisch, D., Groenhagen, U., Bailly, A., Schulz, S., and Weisskopf, L. 2015. Pseudomonas strains naturally associated with potato plants produce volatiles with high potential for inhibition of Phytophthora infestans. Appl. Environ. Microbiol. 81:821-830.

Inceoğlu, Ö., Al-Soud, W. A., Salles, J. F., Semenov, A. V., and van Elsas, J. D. 2011. Comparative analysis of bacterial communities in a potato field as determined by pyrosequencing. PLoS One 6:e23321.

Jones, E. E., Rabeendran, N., and Stewart, A. 2014. Biocontrol of Sclerotinia sclerotiorum infection of cabbage by Coniothyrium minitans and Trichoderma spp. Biocontrol Sci. Technol. 24:1363-1382.

Kai, M., Haustein, M., Molina, F., Petri, A., Scholz, B., and Piechulla, B. 2009. Bacterial volatiles and their action potential. Appl. Microbiol. Biotechnol. 81: 1001-1012.

Kanchiswamy, C. N., Malnoy, M., and Maffei, M. E. 2015. Bioprospecting bacterial and fungal volatiles for sustainable agriculture. Trends Plant Sci. 20: 206-211.

Kloepper, J. W. 1981. Relationship of in vitro antibiosis of plant growthpromoting rhizobacteria to plant growth and the displacement of root microflora. Phytopathology 71:1020.

Koike, A., Subbarao, S. T., Davis, K. V., and Michael, R. 2003. Vegetable diseases caused by soilborne pathogens. UCANR Publ. 8099:12.

Lemfack, M. C., Gohlke, B.-O., Toguem, S. M. T., Preissner, S., Piechulla, B., and Preissner, R. 2018. mVOC 2.0: A database of microbial volatiles. Nucleic Acids Res. 46:D1261-D1265.

Létoffé, S., Audrain, B., Bernier, S. P., Delepierre, M., and Ghigo, J. M. 2014. Aerial exposure to the bacterial volatile compound trimethylamine modifies antibiotic resistance of physically separated bacteria by raising culture medium $\mathrm{pH}$. MBio 5:e00944-13.

Lim, H.-S., Kim, Y.-S., and Kim, S.-D. 1991. Pseudomonas stutzeri YPL-1 genetic transformation and antifungal mechanism against Fusarium solani, an agent of plant root rot. Appl. Environ. Microbiol. 57:510-516.
Love, M. I., Huber, W., and Anders, S. 2014. Moderated estimation of fold change and dispersion for RNA-seq data with DESeq2. Genome Biol. 15:550.

Lucas, P. 2006. Diseases caused by soil-borne pathogens. Pages 373-386 in: The Epidemiology of Plant Diseases. Kluwer Academic Publishers, Dordrecht.

McMurdie, P. J., and Holmes, S. 2013. phyloseq: An R package for reproducible interactive analysis and graphics of microbiome census data. PLoS One 8: e61217.

Mendes, R., Garbeva, P., and Raaijmakers, J. M. 2013. The rhizosphere microbiome: Significance of plant beneficial, plant pathogenic, and human pathogenic microorganisms. FEMS Microbiol. Rev. 37:634-663.

Mendes, R., Kruijt, M., de Bruijn, I., Dekkers, E., van der Voort, M., Schneider, J. H., Piceno, Y. M., DeSantis, T. Z., Andersen, G. L., Bakker, P. A., and Raaijmakers, J. M. 2011. Deciphering the rhizosphere microbiome for disease-suppressive bacteria. Science 332:1097-1100.

Minerdi, D., Bossi, S., Gullino, M. L., and Garibaldi, A. 2009. Volatile organic compounds: A potential direct long-distance mechanism for antagonistic action of Fusarium oxysporum strain MSA 35. Environ. Microbiol. 11: 844-854.

Mnif, I., Grau-Campistany, A., Coronel-León, J., Hammami, I., Triki, M. A., Manresa, A., and Ghribi, D. 2016. Purification and identification of Bacillus subtilis SPB1 lipopeptide biosurfactant exhibiting antifungal activity against Rhizoctonia bataticola and Rhizoctonia solani. Environ. Sci. Pollut. Res. 23: 6690-6699.

Obasa, K., White, F. F., Fellers, J., Kennelly, M., Liu, S., Katz, B., et al. 2017. A dimorphic and virulence-enhancing endosymbiont bacterium discovered in Rhizoctonia solani. Phytobiomes J. 1:14-23.

Ogoshi, A. 1987. Ecology and pathogenicity of anastomosis and intraspecific groups of Rhizoctonia solani Kühn. Annu. Rev. Phytopathol. 25:125-143.

Oksanen, J., Blanchet, F. G., Friendly, M., Kindt, R., Legendre, P., McGlinn, D., Minchin, P. R., O'Hara, R. B., Simpson, G. L., Peter Solymos, P., Stevens, M. H. M., Szoecs, E., and Wagner, H. 2018. vegan: Community Ecology Package. R package version 2.5-3. https://cran.r-project.org/web/packages/ vegan/index.html

Opelt, K., Berg, C., and Berg, G. 2007. The bryophyte genus Sphagnum is a reservoir for powerful and extraordinary antagonists and potentially facultative human pathogens. FEMS Microbiol. Ecol. 61:38-53.

Peighami-Ashnaei, S., Sharifi-Tehrani, A., Ahmadzadeh, M., and Behboudi, K. 2009. Interaction of different media on production and biocontrol efficacy of Pseudomonas fluorescens P-35 and Bacillus subtilis B-3 against grey mould of apple. J. Plant Pathol. 91:65-70.

Popova, A. A., Koksharova, O. A., Lipasova, V. A., Zaitseva, J. V., KatkovaZhukotskaya, O. A., Eremina, S. I., Mironov, A. S., Chernin, L. S., and Khmel, I. A. 2014. Inhibitory and toxic effects of volatiles emitted by strains of Pseudomonas and Serratia on growth and survival of selected microorganisms, Caenorhabditis elegans, and Drosophila melanogaster. BioMed Res. Int. 2014:1-11.

Raaijmakers, J. M., Paulitz, T. C., Steinberg, C., Alabouvette, C., and MoënneLoccoz, Y. 2009. The rhizosphere: A playground and battlefield for soilborne pathogens and beneficial microorganisms. Plant Soil 321:341-361.

Rudrappa, T., Biedrzycki, M. L., Kunjeti, S. G., Donofrio, N. M., Czymmek, K. J., Pare, P. W., and Bais, H. P. 2010. The rhizobacterial elicitor acetoin induces systemic resistance in Arabidopsis thaliana. Commun. Integr. Biol. 3 : 130-138.

Ryu, C.-M. 2004. Bacterial volatiles induce systemic resistance in Arabidopsis. Plant Physiol. 134:1017-1026.

Ryu, C.-M., Farag, M. A., Hu, C.-H., Reddy, M. S., Wei, H.-X., Pare, P. W., and Kloepper, J. W. 2003. Bacterial volatiles promote growth in Arabidopsis. Proc. Natl. Acad. Sci. 100:4927-4932.

Scherwinski, K., Grosch, R., and Berg, G. 2008. Effect of bacterial antagonists on lettuce: Active biocontrol of Rhizoctonia solani and negligible, short-term effects on nontarget microorganisms. FEMS Microbiol. Ecol. 64:106-116.

Schmidt, R., Cordovez, V., De Boer, W., Raaijmakers, J., and Garbeva, P. 2015. Volatile affairs in microbial interactions. ISME J. 9:2329-2335.

Schmidt, R., Etalo, D. W., de Jager, V., Gerards, S., Zweers, H., de Boer, W., and Garbeva, P. 2016. Microbial small talk: Volatiles in fungal-bacterial interactions. Front. Microbiol. 6:1-12.

Schulz, S., and Dickschat, J. S. 2007. Bacterial volatiles: The smell of small organisms. Nat. Prod. Rep. 24:814-842.

Schulz-Bohm, K., Gerards, S., Hundscheid, M., Melenhorst, J., de Boer, W., and Garbeva, P. 2018. Calling from distance: Attraction of soil bacteria by plant root volatiles. ISME J. 12:1252-1262.

Seyedsayamdost, M. R., Traxler, M. F., Clardy, J., and Kolter, R. 2012. Old meets new: Using interspecies interactions to detect secondary metabolite production in Actinomycetes. Methods Enzymol. 517:89-109. 
Shannon, P., Markiel, A., Ozier, O., Baliga, N. S., Wang, J. T., Ramage, D., Amin, N., Schwikowski, B., and Ideker, T. 2003. Cytoscape: A software environment for integrated models of biomolecular interaction networks. Genome Res. 13:2498-2504.

Signorell, A. 2015. DescTools: Tools for descriptive statistics. R package version 0.99.26.

Singh, N., Marwa, N., Mishra, S. K., Mishra, J., Verma, P. C., Rathaur, S., and Singh, N. 2015. Brevundimonas diminuta mediated alleviation of arsenic toxicity and plant growth promotion in Oryza sativa L. Ecotoxicol. Environ. Saf. 125:25-34.

Sneh, B., Jabaji-Hare, S., Neate, S., and Dijs, G. 1996. Rhizoctonia Species: Taxonomy, Molecular Biology, Ecology, Pathology and Disease Control. Kluwer Academic Publishers, Dordrecht.

Soltani, A.-A., Khavazi, K., Asadi-Rahmani, H., Omidvari, M., Abaszadeh Dahaji, P., and Mirhoseyni, H. 2010. Plant growth promoting characteristics in some Flavobacterium spp. isolated from soils of Iran. J. Agric. Sci. 2:106-115.

Spence, C., Alff, E., Johnson, C., Ramos, C., Donofrio, N., Sundaresan, V., and Bais, H. 2014. Natural rice rhizospheric microbes suppress rice blast infections. BMC Plant Biol. 14:130.

Toffano, L., Fialho, M. B., and Pascholati, S. F. 2017. Potential of fumigation of orange fruits with volatile organic compounds produced by Saccharomyces cerevisiae to control citrus black spot disease at postharvest. Biol. Control 108:77-82.

Tyc, O., de Jager, V. C. L., van den Berg, M., Gerards, S., Janssens, T. K. S., Zaagman, N., Kai, M., Svatos, A., Zweers, H., Hordijk, C., Besselink, H., de Boer, W., and Garbeva, P. 2017. Exploring bacterial interspecific interactions for discovery of novel antimicrobial compounds. Microbiol. Biotechnol. 10:910-925.

Tyc, O., van den Berg, M., Gerards, S., van Veen, J. A., Raaijmakers, J. M., de Boer, W., and Garbeva, P. 2014. Impact of interspecific interactions on antimicrobial activity among soil bacteria. Front. Microbiol. 5:567.
Vandenkoornhuyse, P., Quaiser, A., Duhamel, M., Le Van, A., and Dufresne, A. 2015. The importance of the microbiome of the plant holobiont. New Phytol. 206:1196-1206.

Weinert, N., Piceno, Y., Ding, G. C., Meincke, R., Heuer, H., Berg, G., Schloter, M., Andersen, G., and Smalla, K. 2011. PhyloChip hybridization uncovered an enormous bacterial diversity in the rhizosphere of different potato cultivars: Many common and few cultivar-dependent taxa. FEMS Microbiol. Ecol. 75:497-506.

Weller, D. M., Raaijmakers, J. M., Gardener, B. B. M., and Thomashow, L. S. 2002. Microbial populations responsible for specific soil suppressiveness to plant pathogens. Annu. Rev. Phytopathol. 40:309-348.

Wenke, K., Wanke, D., Kilian, J., Berendzen, K., Harter, K., and Piechulla, B. 2012. Volatiles of two growth-inhibiting rhizobacteria commonly engage AtWRKY18 function. Plant J. 70:445-459.

Whipps, J. M. 2001. Microbial interactions and biocontrol in the rhizosphere. J. Exp. Bot. 52:487-511.

Wickham, H. 2016. ggplot2: Elegant Graphics for Data Analysis. Springer, New York.

Wilkins, K. 1996. Volatile metabolites from actinomycetes. Chemosphere 32: 1427-1434.

Xu, Y. Y., Lu, H., Wang, X., Zhang, K. Q., and Li, G. H. 2015. Effect of volatile organic compounds from bacteria on nematodes. Chem. Biodivers. 12: 1415-1421.

Zachow, C., Grosch, R., and Berg, G. 2011. Impact of biotic and abiotic parameters on structure and function of microbial communities living on sclerotia of the soil-borne pathogenic fungus Rhizoctonia solani. Appl. Soil Ecol. 48:193-200. 